\title{
Work- Life Balance as an Indicator of Job Satisfaction Among the Female Bankers in Bangladesh
}

\author{
Mayeesha Fairuz Rahman \\ School of Business Studies, Southeast University, Bangladesh
}

\begin{abstract}
A noteworthy growth of participation of women has been observed in the job market of Bangladesh over the past few years. With the development of the country, its literacy rate and scope of employment, the number of female employees and their contribution is likely to increase further. Among the flourishing sectors of the country, banking is seen to be one of the prominent and fast growing employment sectors where a lot of women are establishing their careers. However, one impediment still remains which obstructs several female bankers to reach the summit of their careers which is the lack of a suitable work-life balance. Hence, this study aims to investigate the importance of work-life balance and the factors that influence their job satisfaction level. Factor Analysis was carried out using SPSS, on the data collected from 128 respondents, which eventually resulted in the extraction of 8 factors, including, Nature of Work, Workplace Support, Work-Life Balance Programs, Healthy \& Stress-free Mind, Salary, Other Monetary Benefits and Job Satisfaction. The study further tested the correlation between the variables identified, followed by a regression analysis to identify the relationship between Work-life Balance and Job Satisfaction for the female bankers in Bangladesh. It is important to note from the findings that Work-life Balance has definitely a substantial impact on Job Satisfaction. However, one predictor variable namely 'Available Personal Time' is found not to have a significant relationship with Job Satisfaction.
\end{abstract}

Keywords: Work-Life Balance, Job Satisfaction, Female Employees and Banking.

DOI: $10.7176 / \mathrm{EJBM} / 11-6-03$

\section{Introduction}

Women comprise of $49.4 \%$ of the population in Bangladesh, which is around half of the total population (Trading Economics, 2016; Countrymeters.info, 2019). The increase in percentage of female labor force has been 4.6 according to the reports of the Bangladesh Bureau of Statistics, while the male labor force increased by 1 . (Islam, 2018), and the total number of female employees according to the International Labor Organization's (ILO) flagship report titled "World Employment and Social Outlook" has been found to be18.1 million in 2017 comprising of $28.4 \%$ of the total workforce (Ovi, 2018). When it comes to the employment sector, besides contributing to the development of an economy through facilitating businesses, banking has become a lucrative segment to build careers in most of the countries worldwide including Bangladesh. As stated by Jamal (2018) from the Daily Star, there are eight state-owned banks, forty privately-owned banks and nine foreign-owned banks, according to Bangladesh Bank (BB) figures of 2017. The banking sector is blooming and many people from both genders are showing acute interest to establish their careers in this particular area, hence, making it an interesting field to examine the factors leading to job satisfaction of the employees in this sector.

According to the Daily Star, the women employment rate in the banking sector as of 2016 was found to be $12.91 \%$, however, the rate of female participation has been comparatively slow than that of their male counterparts in this sector (Chowdhury, 2017). There could be several reasons behind this including the employee perception regarding the presence of work-life balance in their day to day lives. Job satisfaction is one of the most crucial factors when it comes to building career. Besides many factors, work-life balance is considered to be one of the pivotal factors of employee motivation and job satisfaction. "A healthy work-life balance assumes great significance for working women particularly in the current context in which both, the family and the workplace have posed several challenges and problems for women" (Sundaresan, 2014, p.93). Nowadays, businesses are facing increasing demands to raise efficiency and becoming more responsive to customers and employees. Besides remuneration and other extrinsic rewards; job seekers are now making employment decisions on how well their current or potential workplace will be able to support a balance between personal lives and work (Newaz and Zaman, 2012). Studies have found that despite the increase in number of educated women, many of them are struggling to continue working due to the lack of adequate work-life balance. Employees perceive that work-life balance enables them to perform better at work and deem that it should be the responsibility of employer as well as employee to ensure proper balance (Aggarwal 2012), however, bank professionals are finding it very challenging to maintain work-life balance due to the change in work scenario of the industry (Pahuja, 2016).

Since around half of the total population is women in Bangladesh, it is important that this segment is properly utilized as part of the labor force for the socio-economic growth of the country. According to a study by the Families and Work Institute, around $45 \%$ of the women have reported some or a lot of stress related to workplacefamily life balance as cited by (Meenakshi, Subrahmanyam and Ravichandran, 2013). The paper therefore aims to examine the impact of work-life balance on job satisfaction among women in an ever-booming sector like banking 
where there are a lot of female employees as well as to identify which factors of work-life balance have greater influence on employee job satisfaction among females in the banking sector. This study is expected to contribute both academically and practically to the better understanding of how work-life balance can have an impact on the overall job satisfaction levels of the women which hopefully would provide some meaningful insights to the banks in order to attract and retain the talented pool of potential female employees with better planning and execution as well as it will give some idea regarding the working conditions to those women wishing to establish their careers in this specific field.

\section{Literature Review:}

\subsection{Work-life Balance and Job Satisfaction}

Work-life balance has now become of the deeply researched fields of interest. Work-life balance has always been a concern of those interested in the quality of working life and its relation to broader quality of life (Guest, 2002). The concept of work-life has been abstracted from the job satisfaction level of an employee, which is an extrinsic factor of job satisfaction. It aimed to provide quality of life for an employee at the same time retaining the productivity levels of an employee at the work place (Mukhtar, 2012). Strong relationship exists between worklife balance and employee satisfaction; hence companies should make policies and programs for employees on work-life balance. Managers can apply different roles of leadership to manage employees' work-life balance and provide success to the company (Rani, Kamalanabhan and Selvarani, 2011)

Nevertheless, it is also important to know the definition of the underlying concept. Dundas (2008) argues that work- life balance is about effectively managing and juggling act between paid work and all others activities that are important to people such as family, community activities, voluntary work, personal development and leisure and recreation. Job satisfaction refers to the amount of contentment associated with a job. If one loves his/her job, he/she is likely to be highly satisfied with his/her job, where the opposite is true for those who dislike their jobs (Draflke, 2008). There have been multiple benefits of work-life balance such as enhanced levels of job satisfaction, reduced leaving intentions through increased job satisfaction and reduction of work pressures as described by Forsyth and Polzer-Debruyne (2007). On the other hand, another study by Dev (2012), conducted in India has found that work-life balance is positively correlated with job satisfaction in the banking sector. Rehman and Roomi (2012) have found that achieving work life balance is one of the key drivers of motivation for women entrepreneurs. However, still a lot of people are choosing banking as their careers for several reasons. According to Mittal and Mittal (2015), a lot of people in India still want to establish their careers in the field of banking. He also mentioned job stability, scope for people from diversified disciplines and comparatively less stress than other private sector jobs are the main factors besides good salary and added benefits which attract so many people in this field. Thomas (2005), Weerasinghe and Dedunu (2017) have found significant positive impact of wage on job satisfaction. However, other studies have found that employees are not merely satisfied by the pay and promotion mechanisms but they want a greater job security and recognition with less rigid targets (Khan and Parveen, 2014) and (Dangayach, 2012). Work-life Balance of female employees has become an important issue since nowadays people from both genders take the financial responsibility of the family. Hence it is important to understand how the women balance their professional and domestic life (Narayan and Neelima, 2017).

\subsection{Work-Life Balance Programs and Organizational Support}

The increased importance on work life balance has compelled many firms to plan and implement effective worklife balance programs for their employees. Work-life Balance (WLB) programs are being used as a strategic weapon in the competition for the best employees (Nord et al., 2002). According to the Society for Human Resource Management, Work-life programs are financial or time related programs established by an employer that offer employees options to balance professional and personal responsibilities; work-life initiatives are policies and procedures set by a firm with the goal to enable employees to get their jobs done and at the same time provide flexibility to handle personal/family concerns (Lockwood, 2003). In the contemporary competitive world employees prefer to work with organizations that offer family friendly benefits to aid achieving a work-life balance. According to the Community Tool Box at the University of Kansas, a family-friendly workplace or employer is one whose policies make it possible for employees to balance family and work much easily, and to fulfill both their personal and professional obligations (Ctb.ku.edu, n. d.). According to several research, the initiatives may take several forms such as: flex-time, job sharing, voluntary reduced work, parental leave, financial and informational assistance with childcare and eldercare facilities (Beauregard, 2011). However, as cited by Kelly et al. (2014) in a study, in many organizations the flexible work arrangements are only available to some valued employees (Kelly and Kalev, 2006) and employees might suffer from penalties for such practices. (Glass 2004, Leslie et al. 2012, Wharton, Chivers and Blair-Loy, 2008) signifying a lack of employers' willingness to practice such policies. Telecommuting can be defined as a "work arrangements in which employees perform their regular work at a site other than the ordinary workplace, supported by technological connections" (Fitzer, 1997, p.65). According to a survey conducted by Statistics Canada on several telecommuters and survivors, it has been 
revealed that telecommuters were satisfied, respected their work schedule, and were able to organize it in a way that personal commitments did not overlap with work (Pinsonneault and Boisvert, 1999). According to a study done by Bharathi, Mala and Bhattacharya (2015) on 186 women of various IT companies in India, conducive work environment, flexible working hours and working from home are the top three professional enhancement factors regarding work life balance. After conducting a survey on 400 banking staff Oludayo et al. (2015) suggested that work-life balance programs can help to ensure harmonious work flow in the organization, however, satisfaction level could be enhanced if financial incentives were combined with these initiatives. Besides, the work-life balance initiatives taken by the organization, some other factors shaping the relationship at work could also determine job satisfaction level. Factors like poor relations with boss, subordinates or colleagues, difficulties in delegating responsibilities could enhance the anxiety and neuroticism level leading to reduced job satisfaction and adverse effects on mental health (Michie, 2002). On the other hand, a study by Chiaburu and Harrison (2008), mentioned that since coworkers highly influence employee attitudes and their support is associated with job satisfaction, hence, organizations must pay more attention so that these relationships could be enhanced for better organizational outcomes. A survey done on employees for performing a study on employee satisfaction among the major commercial banks in Kenya revealed that only $12 \%$ felt that reward system used affected their performance and affected the organizational growth, whereas significant proportion (39\%) felt that feedback and support of their supervisor plays a pivotal role to enhance their motivation levels (Onzere, 2011). Hence, organizational support is reckoned to be crucial to improve motivation and satisfaction level of workers.

\subsection{Work to Family Conflict}

Women in our community are still found to be the principal care provider of the family including the children and the frail elderly people. As cited by, Colombo and Ghislieri (2008), Greenhaus and Beutell (1985, p.77) defined work-family conflict as "a form of inter-role conflict in which the role pressures from the work and family domains are mutually incompatible in some respect. That is, participation in the work (family) role is made more difficult by virtue of participation in the family (work) role". According to the Australian Institute of Health Welfare as cited by Rice et al. (2008, p.1) "caring is defined as giving assistance and support in response to a need arising in the family or community and primary caring as providing the majority of care for an ongoing period." While primary care has always been one of the top priorities to majority of the women, an increasing pressure from these responsibilities can tend to create a conflict with work. A study conducted by Laxshmi and Gopinath (2013) found that women with low work and family related issues could maintain a better work-life balance than those who had high rate of work and family issues, while previously another study by (Boles, Howard and Donofrio, 2001), revealed that the higher the work-family conflict, the lower the level of job satisfaction (Anuradha and Pandey, 2016). According to ILO Asia-Pacific Working Paper Series, marriage reduces a woman's independence to move a location far from home thus creating a hindrance to work; having children increases the burden of household chores resulting in a discouraging effect on women's participation at work (Rahman and Islam 2013). Employees, more often women are suffering in different sectors including banking due to excessive pressure from work place. Long working hours, taking work home and high responsibilities are adversely affecting family life and responsibilities of employees causing stress among them (Michie, 2002). Study of Mathews, Conger and Wickrama (1996) in St-Amour et al. (2007) revealed that tension of work-life balance results in much higher levels of dissatisfaction with conjugal relationships among women than that of the men. While many women work outside home still child rearing and other household chores remain to be the primary responsibilities of women in many countries including Bangladesh. As stated by Khatun (2018) in the Daily Star, although a large number of women in Bangladesh enter the job market after graduating from universities but their enthusiasm level falls once, they feel the pressure of family responsibilities such as motherhood and other household chores. This signifies that social factors play a pivotal role for even educated women and not letting them to give their best at work which require long working hours and high pressure. Das (2016) mentioned that in the banking sector, workers especially women in the cash have to work in pressure in order to completing account balancing which takes long hours leaving them stressed; the study also pointed out that managing daily household activities, child rearing and looking after the other family members were the prime factors which resulted in stress among female employees in the bank. Hence, these social factors causing stress are likely to have a negative impact on job satisfaction.

\subsection{Impact of Work-life Balance on the Employees' Propensity of Switching/Quitting their Job Field}

The importance of work-life balance is unquestionably important among the contemporary employees especially females. However, it becomes more serious issue to consider when employees are even found to be willing to leave their existing job due to the missing factor of work-life balance in their daily lives. Although pay is one of the most imperative factors but it cannot always buy employee loyalty. As it has been mentioned in Gallup by Robinson (2008) on a research done on 44 organizations, $22 \%$ leave their jobs due to inadequate pay/benefits, however, another $25 \%$ decided to quit their jobs due to lack of flexibility and a proper work environment indicating the importance of the work-life balance factors. On the other hand, according to a Bangladeshi e-newspaper, 
Ourtime, female employees were paid much lower compared to their male counterparts and one of the main reasons they switch their jobs is in order to avail better job opportunities elsewhere in terms of salary and not just for rearing their children (Nusrat, 2016). Khatun (2018) in The Daily Star has mentioned that although the women are ahead of the men in terms of academics but the reverse becomes true when it comes to careers. This might happen due to 'unpaid care work' i.e. looking after the family members and other household chores, according to Deepta Chopra, a women's rights policy expert (Gerrard, 2016). Also, many women leave banking not only of raising their children but because their senior management perceives that 'women leave to have children'. Hence, they are not paid in a just manner if compared to their male colleagues compelling them to move to other job fields (Nitsetska, 2018). In the study done by Neelima and Narayana (2017), the female bankers responded that they constantly face the conflict between work and family. On one hand, family has a lot of expectations from them to fulfill social roles while the organization also wants them to give their level best. Being unable to manage enough time for children, in-laws, parents and their social circle due to the burden of excessive work often forces them to choose between the two. Hence, it has been recommended that the banks should avoid the factors like work on holidays and excessive long working hours and try to incorporate job sharing programs and provide separate policies for work-life balance.

Although a few authors have explored the influence of work-life balance on women in the context of several countries (Das 2016; Lakshmi and Gopinath 2013; Meenakshi, Subrahmanyam and Ravichandran, 2013), there is very little academic evidence on the existing factors behind Job Satisfaction of the female bankers and their perceptions regarding the work-life balance in such a prominent and flourishing employment sector like banking, particularly in Bangladesh. Numerous literature has been extracted in relevance to the importance of work-life balance (Anuradha and Pandey, 2016; Bharathi, Mala and Bhattacharya 2015; Guest, 2002; Narayana and Neelima, 2018), but none of those indicated its impact on the satisfaction level of female employees in the banks of Bangladesh or the factors that are actually motivating them to stick to the sector regardless the weak initiatives regarding work-life balance. The literatures covered on the specific subject form the basis of this particular research paper. All the factors relating to work-life balance and some pertaining factors like Salary and Other monetary rewards have been used to design the research framework and instrument, so that the influence of work-life balance on job satisfaction of female bankers can be analyzed, in Bangladesh.

\section{Research Methodology}

The study attempts to explore what factors relating to work-life balance may affect the job satisfaction level of female bankers in Bangladesh. Hence, to conduct the research, a five-point Likert-scale questionnaire was developed with the help of secondary data gathered from previous literature. The scale ranges from point " 5 ", representing "Strongly Agree", to point "1", which signifies "Strongly Disagree". For sampling purpose in order to generate data, both convenience sampling and random sampling has been used. As part of the convenience sampling, self-administered survey by means of Google Forms were provided to several female bankers known personally by the researcher and the rest of the forms were distributed randomly to female bankers found through social media platforms namely Facebook and Linkedin. From a total of 302 distributed questionnaires, only 146 were returned, however, some extreme/incomplete responses could be found which were then discarded and only 127 were finalized.

The questionnaire distributed consisted of three sections with the first focusing on the background information of the respondents (i.e. age, income, work tenure, designation). The second part included 32 questions that were designed to generate information regarding the factors associated to work-life balance and further influencing factors like salary and other monetary benefits (i.e. independent variables), as well as their effects on job satisfaction level of female bankers in the country (i.e. dependent variable). Finally, the third part was designed to see their propensity to leave their current organization due to their overall satisfaction level and to find out which sectors do they rather wish to work instead of banks.

Eventually, in order to investigate the study, an Exploratory Factor Analysis (EFA) was carried out using the Statistical Package Software for Social Sciences (SPSS.24), followed by reliability test and KMO-Bartlett test. A further Multiple Regression Analysis was done, after the factors were extracted from EFA to assess the relationship between work life balance and job satisfaction of female bankers in Bangladesh. In addition to the abovementioned methods, Frequency Analysis was used to identify the profile of the respondents and explore the sectors they rather wish to work in. 


\section{Data Analysis}

Table 1: Information of the Respondents

\begin{tabular}{|l|l|l|l|}
\hline Variable & Category & Frequency & Percentage (\%) \\
\hline Age & $20-30$ & 39 & 30.7 \\
& $31-40$ & 52 & 40.9 \\
& $41-50$ & 31 & 24.4 \\
& Above 50 & 5 & 3.9 \\
\hline Income Level (in BDT) & Below BDT 20,000 & 4 & 3.1 \\
& BDT20,000-BDT 30,000 & 16 & 12.6 \\
& BDT 31,000- BDT 40,000 & 55 & 43.3 \\
& BDT 41,000- BDT 1,00,000 & 36 & 28.3 \\
& Above BDT 1,00,000 & 16 & 12.6 \\
\hline Job Duration & < year (less than 1 year) & 16 & 12.6 \\
& $1-2$ years & 49 & 38.6 \\
& 3-4 years & 38 & 29.9 \\
& 5-6 years & 17 & 13.4 \\
& $>7$ years & & 5.5 \\
\hline
\end{tabular}

Table 1 illustrates some basic information of the respondents, which exhibits that majority of the respondents, i.e. $40.9 \%$ fall into the age group of 31-40. Majority of the female bankers surveyed have a monthly income level between BDT 31,000 and BDT 40,000 as well as a significant proportion of these women have a monthly income of BDT 41,000-BDT 1, 00,000 which signifies a decent income range in the context of Bangladesh. When asked about their job tenure, it has been found that $39.4 \%$ of the respondents have been working in their current organization for 1-2 years, whereas, only $5.5 \%$ of them are working for more than 7 years, indicating a high attrition rate among women from the sector.

Table 2: Overview of Factor Analysis, Reliability test \& KMO-Bartlett test

\begin{tabular}{|l|l|l|l|l|l|l|}
\hline $\begin{array}{l}\text { Factor } \\
\text { Labeling }\end{array}$ & Factor Items & $\begin{array}{l}\text { EFA } \\
\text { Factor } \\
\text { Loading }\end{array}$ & $\begin{array}{l}\text { Eigen } \\
\text { Value }\end{array}$ & $\begin{array}{l}\text { Variance } \\
\text { Explained } \\
\text { (\%) }\end{array}$ & Alpha & $\begin{array}{l}\text { KMO- } \\
\text { Bartlett } \\
\text { test }\end{array}$ \\
\hline $\begin{array}{l}\text { Nature of } \\
\text { Work }\end{array}$ & $\begin{array}{l}\text { I find myself working for more than } 9 \\
\text { hours on each working day. } \\
\text { I find myself tired quite often due to the } \\
\text { nature of my work. } \\
\text { I find myself unable to manage my work } \\
\text { life }\end{array}$ & $\begin{array}{l}.773 \\
.768\end{array}$ & 9.807 & 28.021 & .661 & .586 \\
\hline $\begin{array}{l}\text { My colleagues especially males are not } \\
\text { always supportive towards their female } \\
\text { Co-workers. } \\
\text { My colleagues do not encourage others } \\
\text { much to succeed or provide helpful } \\
\text { feedback. } \\
\text { My colleagues are not very cooperative } \\
\text { and do not care much about helping others } \\
\text { to maintain a healthy WLB. }\end{array}$ & .723 & 2.147 & 6.133 & .714 & .607 \\
\hline
\end{tabular}




\begin{tabular}{|c|c|c|c|c|c|c|}
\hline $\begin{array}{l}\text { Factor } \\
\text { Labeling }\end{array}$ & Factor Items & \begin{tabular}{l|} 
EFA \\
Factor \\
Loading
\end{tabular} & $\begin{array}{l}\text { Eigen } \\
\text { Value }\end{array}$ & $\begin{array}{l}\text { Variance } \\
\text { Explained } \\
(\%)\end{array}$ & Alpha & $\begin{array}{l}\text { KMO- } \\
\text { Bartlett } \\
\text { test }\end{array}$ \\
\hline $\begin{array}{l}\text { Work-Life } \\
\text { Balance } \\
\text { Programs }\end{array}$ & $\begin{array}{l}\text { The bank management needs to } \\
\text { incorporate counseling services to } \\
\text { personally understand an employee's } \\
\text { concerns. } \\
\text { The bank management should } \\
\text { occasionally arrange social functions } \\
\text { suitable for family members. } \\
\text { The bank management does not allow } \\
\text { enough sick and causal leaves to its } \\
\text { employees annually. } \\
\text { The bank management needs to be more } \\
\text { flexible with its employees to avail early } \\
\text { leaves/late entry for personal } \\
\text { emergencies. } \\
\text { The bank management is not very } \\
\text { encouraging in case of availing earned } \\
\text { leaves. } \\
\text { The bank should provide its employees } \\
\text { with time and facilities for exercise at } \\
\text { work place. } \\
\text { The bank management does not fully } \\
\text { assure employees to return to the same job } \\
\text { after maternity leave without the fear of } \\
\text { losing the job. }\end{array}$ & $\begin{array}{l}.813 \\
.731 \\
.652 \\
.637 \\
.619 \\
.578 \\
.512\end{array}$ & 1.970 & 5.628 & .657 & .767 \\
\hline $\begin{array}{l}\text { Available } \\
\text { Personal } \\
\text { Time }\end{array}$ & $\begin{array}{l}\text { I find myself unable to spend proper time } \\
\text { with my family. } \\
\text { I find myself unable to manage enough } \\
\text { time for personal care due to work } \\
\text { pressure. } \\
\text { I find myself unable to spend quality time } \\
\text { at special events with my dear ones due to } \\
\text { work pressure. }\end{array}$ & $\begin{array}{l}.722 \\
.714 \\
.506\end{array}$ & 1.747 & 4.991 & .608 & 674 \\
\hline $\begin{array}{l}\text { Healthy \& } \\
\text { Stress-free } \\
\text { mind }\end{array}$ & $\begin{array}{l}\text { I often feel motivated to work when there } \\
\text { is less work pressure and less rigid targets. } \\
\text { I often cannot sleep for minimum } 8 \text { hours } \\
\text { due to work-stress. } \\
\text { I often keep thinking about work when I } \\
\text { am not even at work. } \\
\text { I often worry about my family members at } \\
\text { work as I cannot get enough time to fulfill } \\
\text { my personal responsibilities } \\
\text { I often think of doing meditation or yoga } \\
\text { to reduce stress of everyday life. }\end{array}$ & $\begin{array}{l}.875 \\
.819 \\
.732 \\
.583 \\
.509\end{array}$ & 1.593 & 4.550 & .680 & .757 \\
\hline Salary & $\begin{array}{l}\text { The salary I earn is a decent amount for } \\
\text { me and my family. } \\
\text { The salary I get is good enough if } \\
\text { compared to the other sectors in the job } \\
\text { market. } \\
\text { The salary I get is comparable to my male } \\
\text { counterparts. } \\
\text { The salary I get is one of the most } \\
\text { significant reasons of my happiness. }\end{array}$ & $\begin{array}{l}.744 \\
.579 \\
.573 \\
.521\end{array}$ & 1.413 & 4.037 & .709 & .555 \\
\hline
\end{tabular}




\begin{tabular}{|c|c|c|c|c|c|c|}
\hline $\begin{array}{l}\text { Factor } \\
\text { Labeling }\end{array}$ & Factor Items & $\begin{array}{l}\text { EFA } \\
\text { Factor } \\
\text { Loading }\end{array}$ & $\begin{array}{l}\text { Eigen } \\
\text { Value }\end{array}$ & $\begin{array}{l}\text { Variance } \\
\text { Explained } \\
(\%)\end{array}$ & Alpha & $\begin{array}{l}\text { KMO- } \\
\text { Bartlett } \\
\text { test }\end{array}$ \\
\hline $\begin{array}{l}\text { Other } \\
\text { Monetary } \\
\text { Benefits }\end{array}$ & $\begin{array}{l}\text { The employees demonstrating high } \\
\text { performances are justly rewarded with } \\
\text { bonus or other monetary benefits for their } \\
\text { contribution. } \\
\text { The employees get minimum two festival } \\
\text { bonuses annually. } \\
\text { The employees receive an acceptable } \\
\text { annual increment based on their } \\
\text { performances. } \\
\text { The employees receive adequate fringe } \\
\text { benefits such as pension fund, gratuity, } \\
\text { and insurance and so on from the bank. }\end{array}$ & $\begin{array}{l}.714 \\
.557 \\
.516 \\
.507\end{array}$ & 1.292 & 3.692 & .632 & .677 \\
\hline $\begin{array}{l}\text { Job } \\
\text { Satisfaction }\end{array}$ & $\begin{array}{l}\text { I am overall very satisfied with my job. } \\
\text { I am happy and do not intend to switch } \\
\text { from my current job. } \\
\text { I am determined to establish my career in } \\
\text { my current organization. }\end{array}$ & $\begin{array}{l}.678 \\
.609 \\
.521\end{array}$ & 1.228 & 3.508 & .718 & .639 \\
\hline
\end{tabular}

The outcomes of Factor Analysis, Reliability and KMO-Bartlett test have been demonstrated in Table 2 . Conventionally, Factor Analysis has been used to explore the possible underlying structure of a set of irrelated variables without imposing any pre-convinced structure on the outcome (Child, 1990). Exploratory Factor Analysis (EFA) has been used in order to identify the variables, which are significantly compatible and load well in the light of this particular research. Varimax Rotation has aided to extract the most compatible variables as shown in the table, where 3 of the 35 items have been discarded from the table for having values lower than the ideal factor loading coefficient i.e. 0.50 . Using the criterion of retaining only factors for which the Eigen value would be equal to or greater than 1, eight factors have been considered for rotation. The first one is 'Nature of Work' consisting of 3 items and accounted for $28.021 \%$ of explained variance with $\alpha=0.661$. The second factor 'Workplace Support' comprising of 3 items related to the degree of supportive work environment with $6.133 \%$ of explained variance has $\alpha=0.714$. 'Work-Life Balance Programs' is another imperative factor comprising of 7 items such as the need of more flexibility in case of employees availing leaves/ early leaves, the necessity of incorporating counseling services, arranging more social functions and so on to make the employees feel better and less stressed at work. The factor with $5.628 \%$ of explained variance has $\alpha=0.657$. The other vital factors identified are 'Available Personal Time', 'Healthy \& Stress-free mind', 'Salary', 'Other Monetary Benefits', and 'Job Satisfaction' with explained variances of 5.628, 4.991, 4.550, 4.037, 3.692 and 3.508 percent accordingly. From the findings of the study, 'Job Satisfaction' has been reasoned to be the dependent variable, whereas the rest of the seven factors have been considered to be independent variables.

A further validity test has been done using Cronbach's Alpha. Developed by Lee Cronbach in 1951, alpha, measures the internal consistency of a test as cited by Tavagol and Dennick (2011). Although there is no specific or determined lower value of Alpha $(\alpha)$, however, as per cited by George and Mallery (2003, p.231), "_> 9 Excellent, _> 8 - Good,_> .7- Acceptable,_> .6-Questionable, _> .5 - Poor, and < $<$ - Unacceptable." Also, higher the value of $\bar{\alpha}$, the greater will be the reliability of the data (Tavagol and Dennick, 2011). In this study, the range of $\alpha$ varies between 0.608 and 0.714 for all the factors. As a result, it could be deduced that the retained items from the questionnaire are valid and can be considered to be reliable for this research.

The KMO and Bartlett test had also been used in this study to assess the sample correlation in the data set in order to measure how appropriate the data is for the factor analysis. As a general rule the range of KMO falls within $0-1$, where in order to be statistically significant, the value is expected to be greater than 0.50 (Charlotte et al, 2004). It implies that, the larger value of KMO is and closer to 1, the factor analysis of the variable is appropriate. From the above table, it is evident that all the items conceptualized into the eight factors have values of more than 0.50 , ranging from $0.555-0.767$, which means that the test is statistically significant where 'Healthy \& Stress-free mind' is found to have the highest value and 'Salary' has the lowest. 
Table 3: Correlation Coefficients

\begin{tabular}{|l|c|c|c|c|c|c|c|c|}
\hline & \multicolumn{7}{|c|}{ Correlation Coefficients } \\
\cline { 2 - 9 } & $\mathbf{1}$ & $\mathbf{2}$ & $\mathbf{3}$ & $\mathbf{4}$ & $\mathbf{5}$ & $\mathbf{6}$ & $\mathbf{7}$ & $\mathbf{8}$ \\
\hline Nature of Work & - & & & & & & & \\
\hline Workplace Support & $.689^{* *}$ & - & & & & & & \\
\hline Work-Life Balance Programs & $.675^{* *}$ & $.760^{* *}$ & - & & & & & \\
\hline Available Personal Time & .052 & .074 & .060 & - & & & & \\
\hline Healthy \& Stress-free mind & $.688^{* *}$ & $.714^{* *}$ & $.667^{* *}$ & .083 & - & & & \\
\hline Salary & $.435^{* *}$ & $.569^{* *}$ & $.478^{* *}$ & .063 & $.751^{* *}$ & - & & \\
\hline Other Monetary Benefits & $.585^{* *}$ & $.694^{* *}$ & $.644^{* *}$ & .041 & $.672^{* *}$ & $.617^{* *}$ & - & \\
\hline Job Satisfaction & $.462^{* *}$ & $.524^{* *}$ & $.392^{* *}$ & .004 & $.622^{* *}$ & $.587^{* *}$ & $.476^{* *}$ & - \\
\hline$* *$ Correlation is significant at the 0.01 level (2-tailed). & & & & \\
\hline
\end{tabular}

In order to check the impact of work-life balance on Job Satisfaction, it was reckoned crucial to perform a correlation analysis. It can be observed from Table 3 that 'Work-Life Balance Programs' and 'Workplace Support' are most significantly and positively correlated among all the factors. $(\mathrm{r}=0.760, \mathrm{p}<0.01)$ which possibly implies that programs relating to improving work-life balance can help to create a more supportive work environment. Also, if we peer upon the table, we can see that Healthy \& Stress Free mind' is most significantly and positively correlated to 'Job Satisfaction' $(r=0.622, \mathrm{p}<0.01)$ which indicates that less stress and anxiety about work can make these female bankers much happier with their jobs. In addition to this, 'Salary' has a significant positive correlation with 'Job Satisfaction' $(\mathrm{r}=0.587, \mathrm{p}<0.01)$ which reflects that the attractive remuneration package offered by the banks nowadays are attracting these women to stick to the banking sector in spite of the work-life balance impediments. It can be seen from the table that the second independent variable i.e. 'Workplace Support' is also significantly correlated to 'Job Satisfaction' $(r=0.524, \mathrm{p}<0.01)$ which signifies that support from the colleagues and an understanding nature of the management can foster the attitude and satisfaction level of these women towards work. While all the factors are positively correlated with 'Job Satisfaction', the fourth factor from the table, i.e. 'Available Personal Time' is seen to have a statistically insignificant correlation value with 'Job Satisfaction'.

Table 4: Regression Analysis

\begin{tabular}{|c|c|c|c|}
\hline \multicolumn{4}{|l|}{ Regression Model } \\
\hline & Beta $(\beta)$ & $\mathrm{t}$ & Sig. \\
\hline (Constant) & & -2.116 & .000 \\
\hline Nature of Work & .201 & 1.789 & .007 \\
\hline Workplace Support & .266 & 1.573 & .031 \\
\hline Work-Life Balance Programs & .328 & .939 & .004 \\
\hline Available Personal Time & .102 & 1.593 & .086 \\
\hline Healthy \& Stress-free mind & .339 & 2.304 & .008 \\
\hline Salary & .393 & 3.787 & .041 \\
\hline Other Monetary Benefits & .327 & .709 & .005 \\
\hline R Square $\left(\mathrm{R}^{2}\right)$ & \multicolumn{3}{|l|}{.528} \\
\hline Adjusted $\mathrm{R}^{2}$ & \multicolumn{3}{|l|}{.237} \\
\hline \multicolumn{4}{|c|}{ a. Dependent Variable: Job Satisfaction } \\
\hline
\end{tabular}

Table 4 exhibits regression analysis, done to examine all the related variables more comprehensively for further validation of the study. According to Golberg and Cho (2004, p.1) "Regression analysis is a collection of statistical techniques that serve as a basis for drawing inferences about relationships among interrelated variables". The variation in the dependent variable, i.e. 'Job Satisfaction' is explained by the 7 independent variables. All the independent variables are seen to have a positive relationship with the dependent variable, however, one factor, namely 'Available Personal Time' $(\beta=0.102, p=0.086)$ could not be accepted, as the level of acceptance is $p<0.05$. It can be said that the overall strength of association between the independent variables and the target variable is moderately significant with R-square value of 0.528 or $52.8 \%$, which indicates that $52.8 \%$ of the data can be explained by the regression model.

An additional section had been added in the questionnaire to gather insights regarding the alternate sector these female bankers would rather wish to work in so that they could strike a balance between work and personal life. More than $70 \%$ of the respondents did not agree to one of the statements in the questionnaire which stated "I am happy and do not intend to switch from my current job." Among the multiple options given, the highest percentage (21.25) of the respondents, feel that Research \& Consultancy would have been a better option for them to manage work and life balance. Also, a significant proportion of the female bankers feel that NGO/Development could aid them more in case of maintaining a proper work-life balance; the figure is $16.13 \%$. Intriguingly $13.22 \%$ perceives that self-employment could help them more. This signifies that despite the multiple challenges faced by 
women while starting up and running their own businesses, a lot of them infer that entrepreneurship could be a better option for them instead of working in a bank. A similar finding was observed while doing the secondary research, which says that women entrepreneurship has become a pivotal force to the economic growth \& social development of the country, which is reflected by the rise in the number of female entrepreneurs and now it constitutes about $10 \%$ of the total entrepreneurs of Bangladesh (Chowdhury, 2017). In addition, $11.2 \%$ of the female bankers mentioned that they would like to work in the IT/Telecommunication sector rather than the banking sector. According to Ovi (2018), in the Dhaka Tribune, the development in the IT sector is leading to rise in ICT related jobs which in turn is acting as a catalyst to increase the involvement of more female employees in this sector as the women are given more preference in call centers. Hence, this sector is creating opportunities for more potential employees to build their careers and if these women feel that they can maintain a better work-life balance here, then in the future this might become a preferred sector for the women. Rest of the respondents who would like to switch also chose sectors like Hospitality, Education, Beauty Care/Health Fitness and Media/Ad/Event Management. Among these the lowest proportion chose Beauty Care/Health \& Fitness (3.34\%) which is possibly due to the acute divergent nature of work compared to the banking sector where they are currently employed.

\section{Conclusion and Further Scopes of Research}

This study has identified that almost all the predictor variables, namely Nature of Work, Workplace Support, Work- life Balance Programs, Healthy \& Stress-free mind, Salary and Other Monetary benefits have significant influence on the dependent variable i.e. Job Satisfaction. However, one of the factors, Available Personal Time, is found to have no significant relationship with the dependent variable. One limitation to point out regarding the study is the sample size, as more accurate data could possibly be accumulated if a greater number of respondents could be reached out to. Supposedly, there could be more independent variables than the ones identified in this study which can have an influence on the Job Satisfaction of the Bangladeshi female bankers. Moreover, this study has covered the banking segment of the country and the factors relating to work-life balance affecting the satisfaction level of the women in the particular sector and it is believed that a comparative study could be performed by comparing and contrasting the work-life balance scenario in different professions where women are employed. This might not only help the women to compare and choose their preferred professions, given they prioritize work- life balance, but also help the management of different corporate sectors to understand the importance of work- life balance and its impact on job satisfaction which in turn affects the employee performance. Consequently, they can incorporate the necessary mechanisms considering the right balance between work and personal life as it can attract a greater number of potential female employees to work with them.

\section{References}

1. Aggarwal, S. (2012). Balancing Professional and Personal Life: Work Life Balance Study at Indian Oil Corporation Limited. International Journal of Business and Management Tomorrow, 2 (2), pp. 3-11.

2. Anuradha and Pandey, M. (2016). Impact of work-life balance on job satisfaction of women doctors. Problems and Perspectives in Management, 14(2), pp.319-324.

3. Beauregard, T. (2011). Corporate Work-Life Balance Initiatives: Use and Effectiveness. In: S. Kaiser, M. Ringlstetter, D. Eikhof and M. Cunha, ed., Creating Balance?!: International Perspectives on the Work-Life Integration of Professionals. pp. 193-208.

4. Bharathi. S, V., Mala. E, P. and Bhattacharya, S. (2015). Work life balance of women employees in the information technology industry. Asian Journal Of Management Research, [online] 5(3). Available at: https://www.researchgate.net/publication/271446578_Work_Life_Balance_of_Women_Employees_in_the_ Information_Technology_Industry [Accessed 16 Nov. 2018].

5. Boles, J., Howard, W. and Donofrio, H. (2001). An investigation into the inter-relationship of work famly conflict, family work conflict and work satisfaction. Journal of Managerial Issues, 13(3), pp.376-390.

6. Chiaburu, D. and Harrison, D. (2008). Do Peers Make the Place? Conceptual Synthesis and Meta-Analysis of Coworker Effects on Perceptions, Attitudes, OCBs, and Performance. Journal of Applied Psychology, 93 (5), pp. 1082-1103.

7. Child, D. (1990). The essentials of factor analysis, second edition. London, Cassel Educational Limited.

8. Chowdhury, M. M. R. (2017) Challenges for women entrepreneurs. The Daily Star, 25 February. [Online] Available at: https://www.thedailystar.net/education-employment/challenges-women-entrepreneurs-1366573 [Accessed 18 Dec. 2018].

9. Colombo, L. and Ghislieri, C. (2008). The work-to-family conflict: Theories and measures. TPM, [online] 15(1), pp.35-55. Available at: http://www.tpmap.org/tpmap/wp-content/uploads/2014/11/15.1.3.pdf [Accessed 23 Nov. 2018].

10. Countrymeters.info. (2019). Live Bangladesh population (2019) - Countrymeters. [online] Available at: https://countrymeters.info/en/Bangladesh [Accessed 2 Jan. 2019].

11. Ctb.ku.edu. (n.d.). Chapter 25. Changing Policies | Section 11. Promoting Family-Friendly Policies in 
Business and Government | Main Section | Community Tool Box. [online] Available at: https:/ctb.ku.edu/en/table-of-contents/implement/changing-policies/business-government-familyfriendly/main [Accessed 21 Nov. 2018].

12. Dangayach, G. S. M. A. (2012). Analysis of Employee Satisfaction in Banking Sector. International Journal of Humanities and Applied Sciences, 1(2), pp. 78-81.

13. Das, A. (2016). Causes and effects of stress among working women in banking sector, Bangladesh. Mediscope, 3(1), 1-7. doi:10.3329/mediscope.v3i1.29729

14. Dev, G.N., (2012). Employees' perception on work life balance and its relation with job satisfaction in Indian public sector banks. International Journal of Exclusive Management Research, 2(2), pp. 1-13.

15. Draflke, M. (2008). The Human side of Organization. 9th ed. Prentice Hall of India Ltd, pp.300-335.

16. Dundas, K. (2008). Work-Life Balance: There is no 'one-size-fits-all' solution, in K O'Rourke (ed.), Managing Matters. Graduate College of Management, Southern Cross University, New South Wales, Summer (3), pp. 7-8.

17. Fitzer, M. M. (1997). Managing from Afar: Performance and Rewards in a Telecommuting Environment. Compensation and Benefits Review, 29 (1), pp. 65-73.

18. Forsyth, S. and Polzer-Debruyne, A. (2007). The organisational pay-offs for perceived work-life balance support. Asia Pacific Journal of Human Resources, 45(1), pp. 113-123.

19. Gerrard, L. (2016). Why it's so hard for women in Bangladesh to have a career. [Blog] ActionAid. Available at: $\quad$ https://www.actionaid.org.uk/blog/policy-and-research/2016/04/13/why-its-so-hard-for-women-inBangladesh-to-have-a-career [Accessed 16 Nov. 2018].

20. Glass, J. (2004). Blessing or Curse? Work and Occupations, 31(3), pp.367-394.

21. Golberg, M. and Cho, H. (2004). Introduction to Regression Analysis. Las Vegas: Wessex Institute of Technology, WIT press, p.1.

22. Greenhaus, J. and Beutell, N. (1985). Sources of Conflict Between Work and Family Roles. Academy of Management Review, 10(1), pp.76-88.

23. Guest, D. (2002). Perspectives on the Study of Work-life Balance. Social Science Information, 41(2), pp.255279.

24. Gulbahar, Ch, A,a., Kundi, G., Qureshi, Q. and Akhtar, R. (2014). Relationship between Work-Life Balance \& Organizational Commitment. Research on Humanities and Social Sciences, [online] 4(5). Available at: https://www.iiste.org/Journals/index.php/RHSS/article/viewFile/11425/11765 [Accessed 17 Nov. 2018].

25. Kelly, E. and Kalev, A. (2006). Managing flexible work arrangements in US organizations: formalized discretion or 'a right to ask'. Socio-Economic Review, 4(3), pp.379-416.

26. Kelly, E., Moen, P., Oakes, J., Fan, W., Okechukwu, C., Davis, K., Hammer, L., Kossek, E., King, R., Hanson, G., Mierzwa, F. and Casper, L. (2014). Changing Work and Work-Family Conflict. American Sociological Review, 79(3), pp.485-516.

27. Khatun, F. (2018). Women's participation in the job market. The Daily Star. [online] Available at: https://www.thedailystar.net/supplements/womens-participation-the-job-market-1545181 [Accessed 1 Dec. 2018].

28. Lakshmi, K.S., Gopinath, S. (2013). Work-Life Balance of Women Employee With Reference to Teaching Faculties. International Monthly Referred Journal of Research in Management and Technology, 2, pp. 53-62.

29. Leslie, L., Manchester, C., Park, T. and Mehng, S. (2012). Flexible Work Practices: A Source of Career Premiums or Penalties?. Academy of Management Journal, 55(6), pp.1407-1428

30. Lockwood, N.R. (2003). Work/Life Balance Challenges and Solutions. Society for Human Resource Management Research Quarterly. Aonline] Available at: https://www.academia.edu/6531004/Work_Life_Balance_Challenges_and_Solutions [Accessed 21 Nov. 2018].

31. Matthews, L., Conger, R. and Wickrama, K. (1996). Work-family conflict and marital quality: Mediating processes. Social Psychology Quarterly, 59(1), pp.62-79.

32. Meenakshi, S., Subrahmanyam, V. and Ravichandran, K. (2013). The Importance of Work-LifeBalance. IOSR Journal of Business and Management (IOSR-JBM), [online] 14(3), pp.31-35. Available at: http://www.iosrjournals.org/iosr-jbm/papers/Vol14-issue3/F01433135.pdf [Accessed 16 Nov. 2018].

33. Michie, S. (2002). Causes and Management of Stress at Work. Occupational and Environmental Medicine, 59, pp. 67-72.

34. Mittal, S. and Mittal, V. (2015). Employee Commitment in Public and Private Banks in India. International Journal of Business and Management, 10(11), p.199.

35. Mukhtar, F. (2012). Work Life Balance and Job Satisfaction among Faculty at Iowa State University. Ph.D. Iowa State University. (Mukhtar, 2012)

36. Narayana, M. and Neelima, J. (2018). Work life balance on women employees in banking sector: An empirical perspective. International Journal of Advanced Educational Research, 2(5), pp.58-61. 
37. Newaz, M. and Zaman, K. (2012). Work-life balance: Is it still a new concept in private commercial banking sector of Bangladesh?. [online] Consortia Academia. Available at: http://doi.org/10.5861/ijrsm.2012.95 [Accessed 23 Nov. 2018].

38. Nitsetska, S. (2018). I was an associate in IBD. This is why women leave banking. [Blog] eFinancialCareers. Available at: https://news.efinancialcareers.com/uk-en/312491/why-do-women-leave-banking [Accessed 21 Nov. 2018].

39. Nord, W. R., Fox, S., Phoenix, A., and Viano, K. (2002). Real-world reactions to work-life balance programs: Lessons for effective implementation. Organizational Dynamics, 30(3), pp. 223-238.

40. Nusrat, P. (2016). Why Women In Their 30s Are Leaving Their Jobs. Outime. [online] Available at: http://www.ourtimebd.com/beta/2016/04/18/why-women-in-their-30s-are-leaving-their-jobs/ [Accessed 17 Nov. 2018].

41. Oludayo, O., Gberevbie, D., DejiPopoola and Omonijo, D. (2015). A Study of Multiple Work-life Balance Initiatives in Banking Industry in Nigeria. International Research Journal of Finance and Economics, (133).

42. Onzere, H. (2011). Factors that influence Employee Satisfaction in major commercial banks in Kenya. Postgraduate. University of Nairobi.

43. Ovi, I. (2018). Women in workforce: Employment without empowerment. Dhaka Tribune. [online] Available at: $\quad \mathrm{https}: / / w w w . d h a k a t r i b u n e . c o m / b u s i n e s s / 2018 / 03 / 08 /$ women-workforce-employment-withoutempowerment [Accessed 1 Dec. 2018].

44. Pahuja, S. (2016). Work Life Balance of Female Employees: A Case Study. International Research Journal of Management and Commerce, [online] 3(12), pp.41-50. Available at: https://www.researchgate.net/publication/312385528_WORK_LIFE_BALANCE_OF_FEMALES_EMPLO YEES_A_CASE_STUDY [Accessed 17 Nov. 2018].

45. Parveen, S. and Khan, A. (2014). A Study of Employee Satisfaction towards Employer: A Case Study of ICIC Bank. International Journal of Advanced Research in Management and Social Sciences, [online] 3(11), pp.115-128. Available at: http://www.garph.co.uk/IJARMSS/Nov2014/10.pdf [Accessed 16 Nov. 2018].

46. Pinsonneault, A. and Boisvert, M. (1999). The Impacts of Telecommuting on Organizations and Individuals: A Review of the Literature. [online] Expertise.hec.ca. Available at: http://expertise.hec.ca/gresi/wpcontent/uploads/2013/02/cahier9909.pdf [Accessed 21 Nov. 2018].

47. Rani, S., Kamalanabhan and Selvarani (2011). Work/life balance reflections on employee satisfaction. Serbian Journal of Management, [online] 6(1), pp.85 - 96. Available at: https://www.researchgate.net/publication [Accessed 16 Nov. 2018].

48. Rehman, S., and Roomi, M. A. (2012). Gender and work-life balance: a phenomenological study of women entrepreneurs in Pakistan. Journal of Small Business and Enterprise Development, 19(2), pp 209-228. Available at: $\quad$ https://www.researchgate.net/publication/241373413 Gender and worklife balance A phenomenological study of women entrepreneurs in Pakistan [Accessed 16 Nov. 2018].

49. Rice, K., Walker, C., Main, A. and Women's Health Victoria (2008). Women and Informal Care giving. Gender Impact Assessment, 7(i-ii), pp.1-10.

50. Robison, J. (2018). Turning Around Employee Turnover. Gallup. [online] Available at: https://news.gallup.com/businessjournal/106912/turning-around-your-turnover-problem.aspx [Accessed 16 Nov. 2018].

51. Shujat, S., Cheema, F. and Bhutto, F. (2011). Impact of Work Life Balance on Employee Job Satisfaction in Private Banking Sector of Karachi. Journal of Management and Social Sciences, 7(2), pp.8-15.

52. St-Amour, N., Laverdure, J., Devault, A., Manseau, S. and Jacob, R. (2007). The Difficulty of Balancing Work and Family Life: Impact on the Physical and Mental Health of Quebec Families. Quebec: Institut national de sant é publique du Québec.

53. Sundaresan, S. (2014). Work-Life Balance - Implications for Working Women. OIDA International Journal of Sustainable Development, [online] 7(7), pp.102, 2014. Available at: https://papers.ssrn.com/sol3/papers.cfm?abstract id=2505439 [Accessed 1 Dec. 2018].

54. Tavakol, M. and Dennick, R. (2011). Making sense of Cronbach's alpha. International Journal of Medical Education. 2, pp.3-55.

55. Thomas, F. (2005). Job Quality in European Labour Markets. In: S. Bazen, C. Lucifora and W. Salverda, ed., Job Quality and Employer Behaviour. London: Palgrave Macmillan, pp.31-66.

56. Tradingeconomics.com. (2016). Bangladesh - Economic Indicators. [online] Available at: https://tradingeconomics.com/bangladesh/indicators [Accessed 18 Nov. 2018].

57. Weerasinghe, S. and Dedunu, H. (2017). Factors Affecting to Job Satisfaction of Banking Employees in Sri Lanka Special Reference Public and Private Banks in Anuradhapura District. Business and Management Horizons, [online] 5(1). Available at: https://www.researchgate.net/publication

58. Wharton, A., Chivers, S. and Blair-Loy, M. (2008). Use of Formal and Informal Work-Family Policies on the Digital Assembly Line. Work and Occupations, 35(3), pp.327-350. 